\title{
Therapeutic Potential and Recent Advances of Curcumin in the Treatment of Aging-Associated Diseases
}

\author{
Sathish Sundar Dhilip Kumar (), Nicolette Nadene Houreld and Heidi Abrahamse * \\ Laser Research Centre, Faculty of Health Sciences, University of Johannesburg, Johannesburg-2028, South Africa; \\ sathishd@uj.ac.za (S.S.D.K.); nhoureld@uj.ac.za (N.N.H.) \\ * Correspondence: habrahamse@uj.ac.za; Fax.: +27-(11)-559-6448 \\ Received: 16 March 2018; Accepted: 30 March 2018; Published: 5 April 2018

\begin{abstract}
Curcumin, a low molecular weight, lipophilic, major yellow natural polyphenolic, and the most well-known plant-derived compound, is extracted from the rhizomes of the turmeric (Curcuma longa) plant. Curcumin has been demonstrated as an effective therapeutic agent in traditional medicine for the treatment and prevention of different diseases. It has also shown a wide range of biological and pharmacological effects in drug delivery, and has actively been used for the treatment of aging-associated diseases, including cardiovascular diseases, atherosclerosis, neurodegenerative diseases, cancer, rheumatoid arthritis, ocular diseases, osteoporosis, diabetes, hypertension, chronic kidney diseases, chronic inflammation and infection. The functional application and therapeutic potential of curcumin in the treatment of aging-associated diseases is well documented in the literature. This review article focuses mainly on the potential role of plant-derived natural compounds such as curcumin, their mechanism of action and recent advances in the treatment of aging-associated diseases. Moreover, the review briefly recaps on the recent progress made in the preparation of nanocurcumins and their therapeutic potential in clinical research for the treatment of aging-associated diseases.
\end{abstract}

Keywords: curcumin; nanoparticle; plants; natural products; drug delivery; aging

\section{Introduction}

Aging is an inevitable process for all organisms. It creates numerous cellular and molecular malfunctions which lead to the development of various chronic diseases, also generally referred to as aging-associated diseases. The occurrence of aging-associated diseases is increasing worldwide and becoming the leading causes of disability and increased risk of mortality [1-3]. Some of the most common aging-associated diseases are atherosclerosis, cancer, cardiovascular diseases, chronic inflammation, chronic kidney diseases, diabetes, neurodegenerative diseases, hypertension, rheumatoid arthritis, ocular diseases, osteoporosis, and infections [4,5]. Aging-associated diseases usually develop in middle age after the prolonged exposure to an unhealthy early-life environment involving the excessive usage of tobacco and alcohol, anxiety, lack of physical activity and the consumption of a high-fat diet [1]. Clinical trials and epidemiological data has suggested that healthy lifestyle interventions help to prevent many aging-associated chronic diseases, and many can even be reversed [6].

Plant-derived natural products play a vital role in the prevention and treatment of aging-associated diseases [7]. Natural products extracted from plants has been used as an active ingredient in traditional medicine for many centuries [8]. Some plant-derived natural products possess a wide range of biological and pharmacological properties that have become indispensable in modern pharmacotherapy, e.g., paclitaxel (an anticancer drug) from Taxus brevifolia, vincristine and vinblastine 
(anticancer drugs) from Catharanthus roseus, camptothecin (anticancer drug) from Camptotheca acuminata and quercetin (anticancer drug), a polyphenol found in various vegetables and fruits [9-11]. Curcumin, which has the chemical structure 1,7-bis(4-hydroxy-3-methoxyphenyl)-1,6-heptadiene-3,5-dione, is a natural yellow, polyphenolic pigment compound extracted from the rhizomes of turmeric (Curcuma longa), is among these plant-derived natural products $[12,13]$. It is used as a food ingredient in all forms of Indian cuisine, and it shows a wide range of pharmacological activities. It is used for the treatment of neurodegenerative [14], atherosclerosis [15], cardiovascular [16], cancer [17], pulmonary, autoimmune and neoplastic diseases [18], biliary and hepatic disorders [19], diabetes [20], wound healing [21], rheumatoid arthritis [22], chronic inflammation [23], chronic kidney diseases [24], hypertension [25], ocular diseases [26], osteoporosis [27], and skin diseases [28]. Although curcumin possesses good therapeutic efficacy in the treatment of different diseases, the clinical administration of curcumin is difficult due to its poor oral bioavailability, low solubility in aqueous solution, and degradation under physiological conditions [13].

Nanocarrier-mediated delivery aids in overcoming the problems associated with curcumin and facilitates successful delivery without affecting its therapeutic efficacy. Several carrier molecules are used to enhance the bioavailability of curcumin such as polymeric nanoparticles (natural and synthetic polymers), liposomes, dendrimers, solid lipid nanoparticles, and gold nanoparticles [29]. Recent research has suggested that nanoformulated curcumin has a better therapeutic index than the native form of curcumin [30]. In this review article we primarily emphasize the therapeutic potential of curcumin and the possible advantages of using nanocurcumin, which possesses higher stability and increased bioavailability than free curcumin, in the prevention and treatment of aging-associated diseases.

\section{Curcumin}

Turmeric, the golden spice also known as "Indian saffron" is used as a traditional medicine in Southeast Asia [31]. The most important bioactive chemical constituents of turmeric are curcuminoids, which include curcumin, demethoxycurcumin and bisdemethoxycurcumin [32]. Curcumin, a hydrophobic polyphenol, is extracted from the rhizome of the herb Curcuma longa, which belongs to the Zingiberaceae family [33]. It has a wide spectrum of biological and pharmacological activities [34]. Curcumin is less soluble in water and highly soluble in organic solvents including methanol, ethanol, acetone and dimethyl sulfoxide [35]. Curcumin is commonly called diferuloylmethane, and it gives a yellow color to turmeric powder. The chemical structure is shown in Figure 1a. The ultraviolet-visible surface plasmon resonance spectrum of curcumin exhibits a strong absorption peak between $420-430 \mathrm{~nm}$. In the last 10 years, over 15,000 scientific papers have been published on curcumin, and these numbers have been increasing annually. Scopus results for the period 2008-2017 are shown in Figure $1 b$.

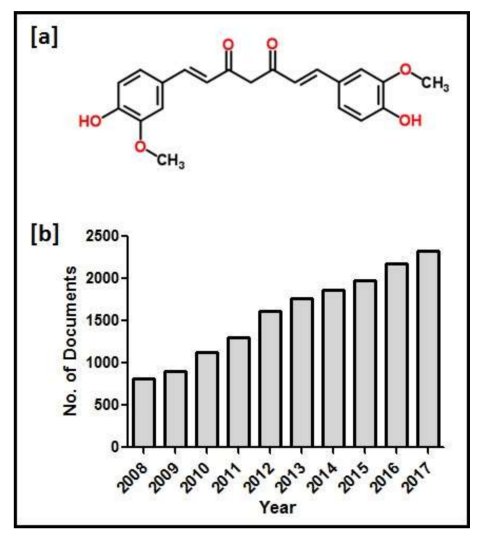

Figure 1. (a) Chemical structure of curcumin; and (b) annual publication history of curcumin (2008-2017). 
An extensive literature survey was conducted over the last 10 years on aging-associated diseases and their treatment strategies using the drug curcumin. Atherosclerosis-curcumin, cancer-curcumin, cardiovascular diseases-curcumin, chronic inflammation-curcumin, chronic kidney diseases-curcumin, diabetes-curcumin, hypertension-curcumin, neurodegenerative diseases-curcumin, ocular diseases-curcumin, osteoporosis-curcumin, and rheumatoid arthritis-curcumin were used as keywords to search the "Scopus" database for the period 2008-2017, and the results are represented in Figure 2. The literature study describes the annual publication history and the recent research progress of curcumin in relation to the above-mentioned aging-associated diseases.

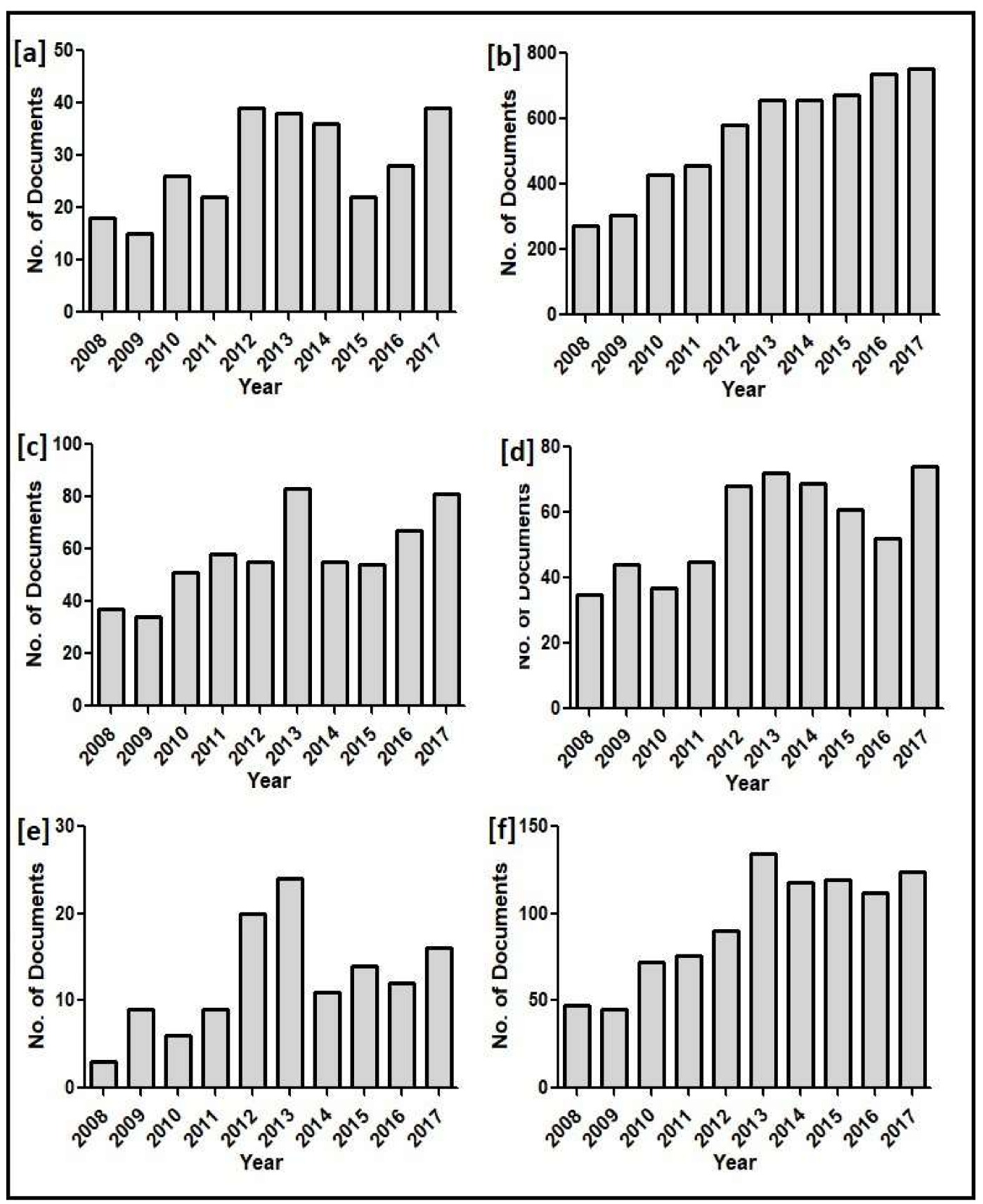

Figure 2. Cont. 

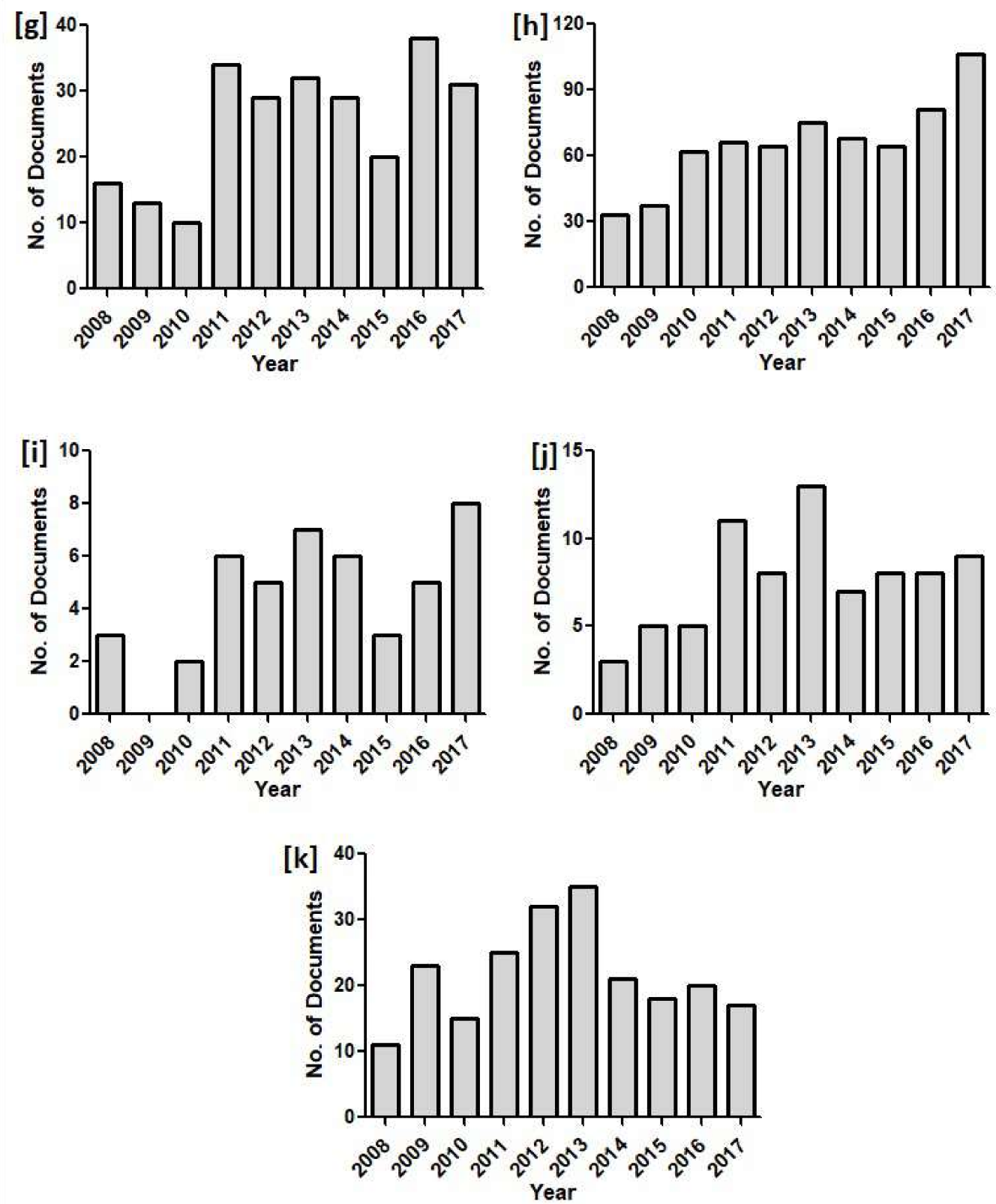

Figure 2. Annual publication history (2008-2017) of curcumin with different aging-associated diseases generated from the "Scopus" database, using the keywords (a) atherosclerosis-curcumin, (b) cancer-curcumin; (c) cardiovascular diseases-curcumin (d) chronic inflammation-curcumin; (e) chronic kidney diseases-curcumin; (f) diabetes-curcumin; (g) hypertension-curcumin; (h) neurodegenerative diseases-curcumin; (i) ocular diseases-curcumin; (j) osteoporosis-curcumin; and (k) rheumatoid arthritis-curcumin.

\section{Biological and Pharmacological Properties of Curcumin}

Currently, curcumin is being investigated as an active therapeutic agent for several types of diseases including cardiovascular, pulmonary, skin disorders, liver disorders, fatigue, neuropathic pain, bone and muscle loss, and anxiety, due to its well reported biological activities which include anti-inflammatory, anti-proliferative, anti-angiogenic, pro-apoptotic, anti-oxidant, wound healing, anti-cancer, anti-viral, and anti-diabetic effects [36-38]. It is a well-recognized plant-based drug for the 
treatment of most chronic diseases. Curcumin has exhibited excellent anti-bacterial activity against both methicillin resistant and sensitive Staphylococcus aureus [39]. It is also one of the most frequently prescribed drugs for the treatment of different skin diseases and skin cancer [28].

Extensive investigation has indicated that curcumin resulted in a reduction in total cholesterol and low-density lipoprotein (LDL) levels in patients suffering from acute coronary syndrome [40], and that it effectively reduced platelet aggregation and hyperlipidemia [41]. Curcumin possesses anti-thrombotic activities and daily consumption helps to maintain anticoagulant status [42]. It can promote cardiac repair and restore cardiac dysfunction [43], molecular understanding in diabetic nephropathy [44], modulate cell cycle regulatory proteins in central nervous system-related disorders including multiple sclerosis [45], and it can be potentially used for the treatment of hepatic diseases [46], and different types of cancers [47]. The beneficial effects of curcumin have also been studied in detail in ocular diseases, which include corneal diseases, eye dryness, conjunctivitis, anterior uveitis, pterygium, regulating calcium hemostasis, cataracts and glaucoma [48].

Various in vitro and in vivo preclinical studies have demonstrated that curcumin has effective biological pharmacological and potential clinical applications by interacting with numerous cellular and molecular targets via a diverse range of mechanisms of action [49], which are presented in Table 1.

Table 1. Diverse range of mechanisms of action of curcumin in aging-associated diseases.

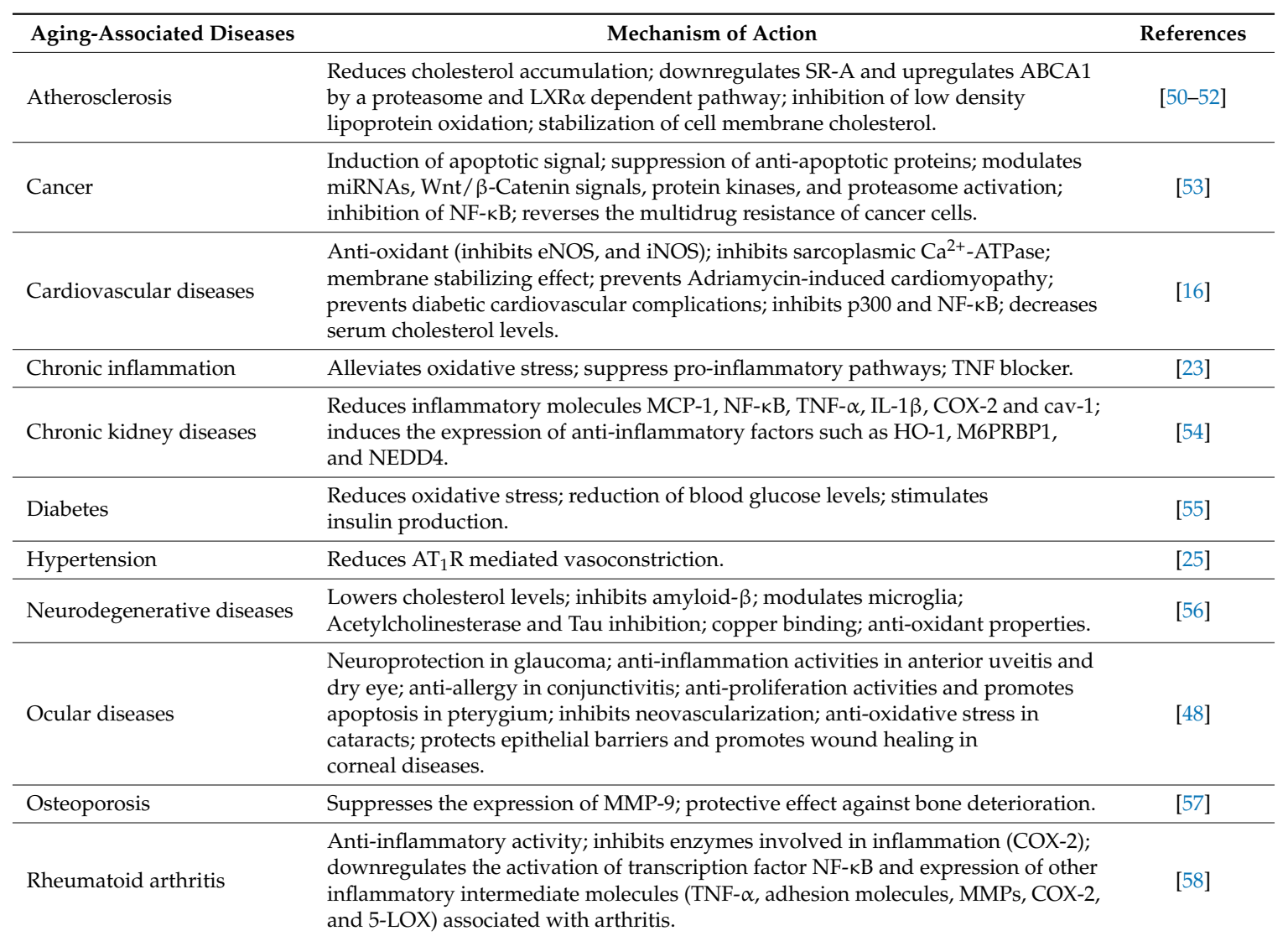

ABCA1-ATP binding cassette family member 1; LXR $\alpha$-Liver X receptor alpha; miRNAs-microRNAs; eNOS - endothelial nitric oxide synthase; NF-кB-Nuclear factor kappa B; iNOS-Inducible nitric oxide synthase; TNF-Tumor necrosis factor; MCP-1-Monocyte Chemoattractant Protein-1; IL-1 $\beta$-Interleukin 1 beta; COX-2 - Cyclooxygenase 2; cav-1-Caveolin 1; HO-1-Heme oxygenase 1; M6PRBP1-Mannose-6-phosphate receptor binding protein 1; NEDD4-neural precursor cell expressed developmentally down-regulated protein 4; AT1R-Angiotensin II receptor type 1; MMP-9-Matrix metallopeptidase 9; MMPs-Matrix metalloproteinase; 5-LOX-5 lipoxygenase. 


\section{Therapeutic Potential of Curcumin in Aging-Associated Diseases}

The aging process is related to a wide range of disorders. Aging-associated diseases are threatening the elderly population worldwide. Research over the last few decades has studied the therapeutic potential of curcumin and showed the beneficial aspects of curcumin in the prevention and treatment of aging-associated diseases. The therapeutic potential of curcumin used in the treatment of aging-associated diseases is discussed in Table 2.

Table 2. Therapeutic potential of curcumin used in the treatment of aging-associated diseases.

\begin{tabular}{|c|c|c|c|}
\hline $\begin{array}{l}\text { Aging-Associated } \\
\text { Diseases }\end{array}$ & $\begin{array}{c}\text { Therapeutic Potential } \\
\text { of Curcumin }\end{array}$ & Outcomes & References \\
\hline Atherosclerosis & $\begin{array}{l}\text { Anti-atherogenic effect of } \\
\text { curcumin via different } \\
\text { mechanisms. }\end{array}$ & $\begin{array}{l}\text { The effect of curcumin was studied and compared with the drug } \\
\text { lovastatin, and the long-term treatment with curcumin lowered } \\
\text { plasma and hepatic cholesterol, and suppressed early } \\
\text { atherosclerotic lesions. }\end{array}$ & [59] \\
\hline Cancer & $\begin{array}{l}\text { Curcumin interferes with } \\
\text { multiple cell signaling } \\
\text { pathways which include cell } \\
\text { cycle, apoptosis, proliferation, } \\
\text { angiogenesis, invasion, } \\
\text { metastasis and inflammation. }\end{array}$ & $\begin{array}{l}\text { The anticancer activity of curcumin was reported against different } \\
\text { cancers, and it plays a significant role in different cell signaling } \\
\text { pathway and numerous molecular targets. The in vitro, in vivo and } \\
\text { clinical studies revealed the therapeutic value of curcumin for the } \\
\text { treatment of "old-age" diseases like cancer. }\end{array}$ & [60] \\
\hline $\begin{array}{l}\text { Cardiovascular } \\
\text { diseases }\end{array}$ & $\begin{array}{l}\text { The inflammatory effects of } \\
\text { curcumin may play a key role } \\
\text { in the prevention of } \\
\text { cardiovascular diseases. }\end{array}$ & $\begin{array}{l}\text { Curcumin showed the possibility of preventing atrial arrhythmias } \\
\text { and some ventricular arrhythmias. }\end{array}$ & [16] \\
\hline $\begin{array}{l}\text { Chronic } \\
\text { inflammation }\end{array}$ & $\begin{array}{l}\text { Curcumin can suppress both } \\
\text { acute and chronic } \\
\text { inflammation by scavenging } \\
\text { reactive oxygen species and } \\
\text { enhancing antioxidant } \\
\text { defences. }\end{array}$ & $\begin{array}{l}\text { Curcumin shows very good antioxidant properties, and it plays a } \\
\text { key role in the prevention and treatment of chronic inflammation. }\end{array}$ & {$[23,61]$} \\
\hline $\begin{array}{l}\text { Chronic kidney } \\
\text { diseases }\end{array}$ & $\begin{array}{l}\text { Curcumin increases the } \\
\text { expression of intestinal } \\
\text { alkaline phosphatase and tight } \\
\text { junction proteins. }\end{array}$ & $\begin{array}{l}\text { The study shows the potential anti-inflammatory effects of } \\
\text { curcumin and their positive effects for the treatment of chronic } \\
\text { kidney diseases. }\end{array}$ & [24] \\
\hline Diabetes & $\begin{array}{l}\text { Curcumin reduces glycemia } \\
\text { and hyperlipidemia in rodent } \\
\text { models, and favourably affects } \\
\text { some leading aspects of } \\
\text { diabetes which include insulin } \\
\text { resistance, hyperglycemia and } \\
\text { islet apoptosis and necrosis. }\end{array}$ & $\begin{array}{l}\text { Curcumin is actively involved in the prevention and treatment of } \\
\text { diabetes. The study showed that curcumin and their complexes can } \\
\text { successfully be used for the treatment of various disorders } \\
\text { associated with diabetes such as liver disorders, adipose tissue } \\
\text { dysfunction, diabetic neuropathy, diabetic nephropathy, diabetic } \\
\text { vascular disease, and other complications associated with diabetes. }\end{array}$ & [20] \\
\hline Hypertension & $\begin{array}{l}\text { Curcumin shows beneficial } \\
\text { effects on hypertension; it } \\
\text { prevents the development of } \\
\text { hypertension by regulating } \\
\mathrm{AT}_{1} \text { receptor expression. }\end{array}$ & $\begin{array}{l}\text { The study was performed using curcumin in an Ang II-induced } \\
\text { hypertensive model, and it showed that curcumin aids in the } \\
\text { downregulation of the } \mathrm{AT}_{1} \text { receptor in } \mathrm{A} 10 \text { cells and it subsequently } \\
\text { prevents hypertension. }\end{array}$ & [25] \\
\hline $\begin{array}{l}\text { Neurodegenerative } \\
\text { diseases }\end{array}$ & $\begin{array}{l}\text { Curcumin has reported to be } \\
\text { an effective neuroprotective } \\
\text { agent and it may prevent } \\
\text { aging associated changes in } \\
\text { cellular proteins. }\end{array}$ & $\begin{array}{l}\text { Protein homeostasis plays an important role in aging-associated } \\
\text { diseases. The study performed in an invertebrate model } \\
\text { (Caenorhabditis elegans) showed that the drug curcumin aids to } \\
\text { maintain protein homeostasis and increases the life span of the } \\
\text { model organism. Several animal model studies showed that } \\
\text { curcumin prevents or delays various neurodegenerative diseases. }\end{array}$ & [14] \\
\hline Ocular diseases & $\begin{array}{l}\text { Curcumin exhibits potential } \\
\text { therapeutic activity against } \\
\text { several ocular diseases. }\end{array}$ & $\begin{array}{l}\text { Curcumin showed beneficial effects in the prevention and treatment } \\
\text { of several ocular diseases. The dosage of curcumin, up to } 8 \mathrm{~g} / \text { day } \\
\text { for three months, does not produce any dose-limiting toxicity in } \\
\text { pharmacological studies. Clinical data proved that the few weeks of } \\
\text { curcumin treatment reduced the signs and symptoms of eye } \\
\text { discomfort and is safe in the treatment of humans. }\end{array}$ & [26] \\
\hline Osteoporosis & $\begin{array}{l}\text { Curcumin may be a potential } \\
\text { candidate for the treatment of } \\
\text { osteoporosis. }\end{array}$ & $\begin{array}{l}\text { The protective effects of curcumin were studied against } \\
\text { dexamethasone induced osteoporosis in a rat model. The results } \\
\text { proved that curcumin effectively prevented glucocorticoid- induced } \\
\text { osteoporosis. }\end{array}$ & [27] \\
\hline Rheumatoid arthritis & $\begin{array}{l}\text { Curcumin possess various } \\
\text { pharmacological activities } \\
\text { including antiarthritic effects. }\end{array}$ & $\begin{array}{l}\text { The effect of curcumin was studied in an adjuvant-induced arthritis } \\
\text { rat model, and it showed similar therapeutic effects for the } \\
\text { treatment of rheumatoid arthritis compared with the drug } \\
\text { methotrexate. }\end{array}$ & [22] \\
\hline
\end{tabular}

\section{Recent Advances of Nanocurcumin in Aging-Associated Diseases}

In recent years, nanotechnology-based drug delivery systems have received considerable attention in drug delivery and pharmaceutical research due to their capability to deliver drugs and other 
substances (such as targeting ligands, fluorescent dyes) to the targeted region. Nanoformulation offers distinct advantages in drug delivery which include lack of toxicity, high drug loading capacity, controlled drug release, extended shelf life period, higher stability, functionalization with specific targets, intracellular release and targeted delivery [62]. Various nano-based formulations are successfully studied for imaging, diagnostic and therapeutic applications [63]. Recent advances in nanotechnology have facilitated the formulation of nanocurcumin and it significantly improved the therapeutic efficacy and bioavailability of its native counterpart [64] and provides the opportunity for disease specific targeting [65].

Curcumin-loaded spherical polymeric nanoconstructs with lipid chains was assessed in vitro using RAW 264.7 cells. The nanoconstructs significantly modulated the production of pro-inflammatory cytokines without any cytotoxic effect [66]. Curcumin-conjugated magnetic nanoparticles bind with amyloid plaques in mouse brains, which was confirmed through immunohistochemical studies and magnetic resonance images. This study revealed the potential application of curcumin magnetic nanoparticles to visualize amyloid plaques in Alzheimer's disease [67]. Curcumin loaded zinc oxide nanoparticles encapsulated with a co-polymer were successfully synthesized, and their anticancer activity showed excellent cytotoxicity effects in AGS gastric cancer cells [68]. In vitro and in vivo studies showed that curcumin encapsulated PLGA nanoparticles showed effective targeting and growth inhibition of prostate cancer cells [69]. Meena et al. synthesized small positively charged curcumin nanoparticles using PLGA as a carrier, and tested these nanoparticles in triple-negative breast cancer cells. Nanocurcumin showed higher cellular incorporation and produced more cytotoxic effects than free curcumin, and further apoptosis induction occurred due to DNA damage [70]. Fan et al. fabricated curcumin loaded nanoparticles using bovine serum albumin and dextran as a carrier molecule, and showed improved cellular antioxidant activity in Caco-2 cells [71]. Curcumin loaded solid lipid nanoparticles were synthesized and were revealed as a safe and effective therapeutic agent for the treatment of lipopolysaccharide-induced sepsis in IL-1b transgenic mice [72]. Curcumin nanoparticles possessed cardio protection against palmitate induced cardiomyocyte apoptosis in H9C2 embryonic rat heart-derived cells, and may be an alternative treatment for lipid toxicity and myocardial injury [73]. Dewangan et al. prepared curcumin-carboxymethyl cellulose acetate butyrate nanoparticles in the size range of $166.5 \pm 4.2 \mathrm{~nm}$ with higher loading efficiency. This study demonstrated superior anti-inflammatory effects without any specific side effects for the successful treatment on adjuvant induced arthritis in rats [74]. The curcumin encapsulated PLGA nanoparticle approach enhanced the effect of curcumin against bone loss. It showed significant beneficial effects on osteoporotic bone loss treatment with an improved therapeutic index [75]. Curcumin encapsulation was performed using a novel nanomicelle formulation which significantly improved in vitro cellular uptake and in vivo corneal permeation as compared to free curcumin [76]. Some to the recent advances in the preparation of nanocurcumin for the treatment of aging-associated diseases are well studied and are listed in Table 3.

Table 3. Recent advances in the preparation of nanocurcumin for the treatment of aging-associated diseases.

\begin{tabular}{llll}
\hline $\begin{array}{c}\text { Aging-Associated } \\
\text { Diseases }\end{array}$ & Detail of Nanoparticles & Size (nm) & Outcomes \\
\hline Cancer & $\begin{array}{l}\text { Curcumin loaded cationic } \\
\text { liposome- polyethylene glycol } \\
\text { (PEG) and poly (ethylene } \\
\text { imine) complex }\end{array}$ & $270 \mathrm{~nm}$ & $\begin{array}{l}\text { Curcumin liposomes showed five-fold cytotoxic activity } \\
\text { on curcumin-sensitive cells and twenty-fold against } \\
\text { curcumin-resistant cells compared to native curcumin, } \\
\text { and achieved } 45 \pm 0.2 \% \text { curcumin encapsulation } \\
\text { efficiency in the liposome complex. In vivo studies } \\
\text { showed that the administration of curcumin liposomes } \\
\text { inhibited 60-90\% of tumor growth. }\end{array}$ \\
\hline Cancer & & $\begin{array}{l}\text { Curcumin loaded silk fibroin nanoparticles were } \\
\text { synthesized using both physical adsorption (drug } \\
\text { loading content of } 6.63 \pm 0.09 \% \text { and encapsulation } \\
\text { efficiency of } 53.75 \pm 0.81 \%) \text { and co-precipitation (drug } \\
\text { loading content of } 2.47 \pm 0.11 \% \text { and encapsulation } \\
\text { efficiency of } 48.84 \pm 2.67 \%) \text {. The synthesized material } \\
\text { showed excellent antitumor activity against both Hep3B } \\
\text { and Kelly cells. }\end{array}$ \\
\hline
\end{tabular}


Table 3. Cont.

\begin{tabular}{|c|c|c|c|c|}
\hline $\begin{array}{l}\text { Aging-Associated } \\
\text { Diseases }\end{array}$ & Detail of Nanoparticles & Size (nm) & Outcomes & References \\
\hline $\begin{array}{l}\text { Cardiovascular } \\
\text { diseases }\end{array}$ & $\begin{array}{l}\text { Colloidal nanoparticles } \\
\text { (Curcumin with gum ghatti } \\
\text { solution) }\end{array}$ & $190 \mathrm{~nm}$ & $\begin{array}{l}\text { A small amount of synthesized colloidal curcumin } \\
\text { nanoparticles could be more therapeutically effective for } \\
\text { heart failure than native curcumin. }\end{array}$ & [79] \\
\hline $\begin{array}{l}\text { Chronic } \\
\text { inflammation }\end{array}$ & $\begin{array}{l}\text { Nano-emulsified curcumin } \\
\text { (NEC) }\end{array}$ & - & $\begin{array}{l}\text { NEC was orally supplied to NZM } 2410 \text { mice (lupus } \\
\text { nephritis model) and kidney function was monitored by } \\
\text { testing blood urea nitrogen. Results suggested that NEC } \\
\text { has a good therapeutic potential in the treatment of } \\
\text { chronic inflammation and other autoimmune diseases. }\end{array}$ & [80] \\
\hline $\begin{array}{l}\text { Chronic kidney } \\
\text { diseases }\end{array}$ & Curcumin nanoparticles & $80-100 \mathrm{~nm}$ & $\begin{array}{l}\text { The in vitro and in vivo study suggested that the } \\
\text { curcumin nanoparticles enhanced the treatment efficacy } \\
\text { of Rhabdomyolysis induced acute kidney injury than } \\
\text { free curcumin. The release study was performed using } \\
\text { dialysis. The initial } 20 \mathrm{~h} \text { of dialysis showed that upto } \\
40 \% \text { of curcumin nanoparticles were released and } 80 \% \text { of } \\
\text { free curcumin was released. Nanoparticulate curcumin } \\
\text { achieved prolonged release profile than free curcumin. }\end{array}$ & [81] \\
\hline $\begin{array}{l}\text { Neurodegenerative } \\
\text { diseases }\end{array}$ & $\begin{array}{l}\text { Nanocurcumin (Curcumin } \\
\text { loaded p(PEG-poly-lactic acid) } \\
\text { micelles }\end{array}$ & $80 \mathrm{~nm}$ & $\begin{array}{l}\text { There was improved bioavailability of nanocurcumin in } \\
\text { the brains of Tg2576 mice as compared to free curcumin, } \\
\text { and nanocurcumin showed positive effects in the } \\
\text { treatment of Alzheimer's disease. The entrapment } \\
\text { efficiency of curcumin was almost } 100 \% \text { and the loading } \\
\text { efficiency of curcumin was } 37.6 \% \text {. }\end{array}$ & [82] \\
\hline Ocular diseases & $\begin{array}{l}\text { Curcumin encapsulated PLGA } \\
\text { nanoparticles }\end{array}$ & $282.50 \pm 5.72 \mathrm{~nm}$ & $\begin{array}{l}\text { The study demonstrated the potential of curcumin } \\
\text { encapsulated nanoparticles in managing diabetic } \\
\text { cataracts in a streptozotocin induced diabetic rat cataract } \\
\text { model. The enhanced performance of nanocurcumin } \\
\text { was observed in different biochemical pathways than } \\
\text { free curcumin. It may be due to the improved oral } \\
\text { bioavailability of curcumin. }\end{array}$ & [83] \\
\hline Osteoporosis & $\begin{array}{l}\text { Gold nanoparticles } \\
\text { functionalized with } \\
\text { cyclodextrin curcumin } \\
\text { complexes }\end{array}$ & $36.3 \mathrm{~nm}$ & $\begin{array}{l}\text { Loading efficiency of curcumin was around } 38.95 \% \text { and } \\
\text { the curcumin loaded nanoparticle complex showed an } \\
\text { effective intracellular uptake and acts as a potential } \\
\text { therapeutic agent in the treatment of bone diseases } \\
\text { associated with excessive bone resorption. }\end{array}$ & [84] \\
\hline $\begin{array}{l}\text { Rheumatoid } \\
\text { arthritis }\end{array}$ & $\begin{array}{l}\text { Curcumin nanoemulsion } \\
\text { (curcumin, solutol-HS 15, } \\
\text { soybean oil) }\end{array}$ & $150 \mathrm{~nm}$ & $\begin{array}{l}\text { In vivo rat study showed that the synthesized curcumin } \\
\text { nanoemulsion acts as an effective antiarthritic agent. } \\
\text { The oral route of curcumin nanoemulsion showed } \\
\text { threefold increase of AUC (area under the curve) and } \\
\mathrm{C}_{\max } \text { value than the suspension (intravenous (iv) route) } \\
\text { and it significantly enhanced the drug absorption than } \\
\text { free curcumin. Overall, the in vivo rat study suggested } \\
\text { that the nanoform of curcumin aids to convert the } \\
\text { therapy route from iv to oral administration for the } \\
\text { effective treatment of RA therapy }\end{array}$ & [22] \\
\hline
\end{tabular}

\section{Clinical Application of Curcumin in Aging-Associated Diseases}

Curcumin has been extensively used in clinical trials and is showing positive outcomes for the treatment of aging-associated diseases. The global market is predominantly focused on curcumin as a health supplement due to its effective antioxidant and anti-inflammatory properties [39]. The different aging-associated diseases along with curcumin were used as a keyword to search the "https:/ / clinicaltrials.gov" database. The number of clinical trials are listed in Table 4 and some of the major global clinical trial status of curcumin in aging-associated diseases are listed in Table 5.

Table 4. Number of clinical trials generated from the "https: / clinicaltrials.gov" database using the keywords (curcumin and the different aging-associated diseases).

\begin{tabular}{cc}
\hline Keywords Used & No. of Studies Found \\
\hline Atherosclerosis-curcumin & 1 \\
Cancer-curcumin & 57 \\
Cardiovascular diseases-curcumin & 9 \\
Chronic inflammation-curcumin & 2 \\
Chronic kidney diseases-curcumin & 5 \\
Diabetes-curcumin & 11 \\
Hypertension-curcumin & 1 \\
Neurodegenerative diseases-curcumin & 6 \\
\hline
\end{tabular}


Table 4. Cont.

\begin{tabular}{cc}
\hline Keywords Used & No. of Studies Found \\
\hline Ocular diseases-curcumin & 4 \\
Osteoporosis-curcumin & 0 \\
Rheumatoid arthritis-curcumin & 2 \\
\hline
\end{tabular}

Table 5. Status of some of the major global clinical trials of curcumin in aging-associated diseases.

\begin{tabular}{|c|c|c|c|c|c|}
\hline $\begin{array}{l}\text { ClinicalTrials.gov } \\
\text { Identifier }\end{array}$ & Ages (Years) & Disease & Doses of Curcumin & Phase & Reference \\
\hline NCT02998918 & 18 to 60 (Adult) & $\begin{array}{l}\text { Inflammation } \\
\text { Atherosclerosis } \\
\text { Cardiovascular Disease }\end{array}$ & $\begin{array}{l}500 \mathrm{mg} \text { of curcumin phytosome } \\
\text { twice daily for } 1 \text { week }\end{array}$ & 2 & [85] \\
\hline NCT00973869 & $\begin{array}{l}18 \text { and older } \\
\text { (Adult, Senior) }\end{array}$ & Colorectal cancer & $\begin{array}{l}\text { Oral curcumin once daily for } \\
\text { 14-28 days }\end{array}$ & 1 & [86] \\
\hline NCT02099890 & $\begin{array}{l}18 \text { and older } \\
\text { (Adult, Senior) }\end{array}$ & $\begin{array}{l}\text { Neuropathic pain; } \\
\text { Depression; } \\
\text { Cognitive impairment; } \\
\text { Somatic neuropathy; } \\
\text { Autonomic dysfunction }\end{array}$ & $\begin{array}{l}\text { InflanNox capsule ( } 400 \mathrm{mg} \\
\text { curcumin) taken } 3 \text { times daily } \\
\text { along with other } \\
\text { anti-inflammatory supplements }\end{array}$ & 3 & [87] \\
\hline NCT02369549 & $\begin{array}{l}18 \text { and older } \\
\text { (Adult, Senior) }\end{array}$ & Chronic kidney disease & $\begin{array}{l}\text { Three } 30 \mathrm{mg} \text { capsules of } \\
\text { micro-particle curcumin daily in } \\
\text { the morning }\end{array}$ & 3 & [88] \\
\hline NCT02529969 & 40 to 65 (Adult) & $\begin{array}{l}\text { Non-insulin dependent } \\
\text { diabetes }\end{array}$ & $500 \mathrm{mg}$ curcumin capsule & 2 & [89] \\
\hline NCT02984813 & $\begin{array}{l}18 \text { and older } \\
\text { (Adult, Senior) }\end{array}$ & $\begin{array}{l}\text { Open-angle glaucoma } \\
\text { diabetic retinopathy }\end{array}$ & $\begin{array}{l}\text { Two pills daily (one contains } \\
\text { curcumin and other contains } \\
\text { active compounds) for } 3 \text { months }\end{array}$ & 1 & [90] \\
\hline NCT00164749 & $\begin{array}{l}50 \text { and older } \\
\text { (Adult, Senior) }\end{array}$ & Alzheimer's disease & $\begin{array}{l}\text { Two different dosages }(1 \mathrm{~g} / \text { day } \\
\text { and } 4 \mathrm{~g} / \text { day) along with ginkgo } \\
\text { extract }\end{array}$ & 2 & [91] \\
\hline NCT00752154 & $\begin{array}{l}18 \text { and older } \\
\text { (Adult, Senior) }\end{array}$ & Rheumatoid arthritis & $\begin{array}{l}\left.\text { Curcumin (Longvida }{ }^{\mathrm{TM}}\right) 4 \\
\text { capsules approximately } 2 \mathrm{~g} / \text { day } \\
\text { for } 2 \text { weeks, then the dose will be } \\
\text { increased to } 4 \text { capsules twice a } \\
\text { day }(4 \mathrm{~g} / \text { day) }\end{array}$ & $\begin{array}{l}\text { Early } \\
\text { phase } 1\end{array}$ & [92] \\
\hline
\end{tabular}

\section{Future Perspectives and Conclusions}

In this review, we discussed in some detail the therapeutic potential of curcumin for the prevention and treatment of aging-associated diseases. Curcumin is a well-known plant-derived compound that exhibits a wide range of biological and pharmacological effects in modern medicine. It is well documented in the literature and shows positive effects on the treatment of aging-associated diseases. However, despite the fact that the native form of curcumin possesses good therapeutic efficacy, the clinical administration is problematic due to their poor oral bioavailability and stability. Recent advances in nanotechnology have helped to overcome these difficulties and efficiently deliver curcumin to the targeted region thereby improving curcumin bioavailability. An extensive literature study strongly suggests that the nanocarrier-mediated delivery of curcumin will become a successful treatment strategy for aging-associated diseases. Moreover, future perspectives should include additional clinical trial investigations on the formulation of nanocurcumin with improved stability and oral bioavailability, and focus more on targeted drug delivery of curcumin for the treatment of aging-associated diseases.

Acknowledgments: Sathish Sundar Dhilip Kumar is supported by funding from the Claude Leon Foundation, South Africa. This work is based on the research supported by the South African Research Chairs Initiative of the Department of Science and Technology and National Research Foundation of South Africa (Grant No. 98337), as well as grants received from the University of Johannesburg (URC), the National Research Foundation (NRF), and the CSIR (Council for Scientific and industrial Research)—NLC (National Laser Centre) Laser Rental Pool Programme. 
Author Contributions: S.S.D.K. conceptualized the idea and prepared the review article. N.N.H. was involved in drafting the manuscript, revising it critically for intellectual content, provided professional guidance and is the supervisor of lead author. H.A. organized this study, supplied editorial input and is a co-supervisor of the lead author. All authors read and approved the final manuscript.

Conflicts of Interest: The authors confirm that this article content has no conflict of interest.

\section{References}

1. Prasad, S.; Sung, B.; Aggarwal, B.B. Age-associated chronic diseases requires age-old medicine: Role of chronic inflammation. Prev. Med. 2012, 54, S29-S37. [CrossRef] [PubMed]

2. Tarry-Adkins, J.L.; Ozanne, S.E. Nutrition in early life and age-associated diseases. Ageing Res. Rev. 2017, 39, 96-105. [CrossRef] [PubMed]

3. Ahmad, A.; Banerjee, S.; Wang, Z.; Kong, D.; Majumdar, A.P.N.; Sarkar, F.H. Aging and Inflammation: Etiological culprits of cancer. Curr. Aging Sci. 2009, 2, 174-186. [CrossRef] [PubMed]

4. Tosato, M.; Zamboni, V.; Ferrini, A.; Cesari, M. The aging process and potential interventions to extend life expectancy. Clin. Interv. Aging 2007, 2, 401-412. [PubMed]

5. Kithas, P.A.; Supiano, M.A. Hypertension and chronic kidney disease in the elderly. Adv. Chronic Kidney Dis. 2010, 17, 341-347. [CrossRef] [PubMed]

6. Fontana, L. Modulating Human Aging and Age-Associated Diseases. Biochim. Biophys. Acta 2009, 1790, 1133-1138. [CrossRef] [PubMed]

7. Szymanska, R.; Pospisil, P.; Kruk, J. Plant-derived antioxidants in disease prevention. Oxid. Med. Cell Longev. 2016. [CrossRef] [PubMed]

8. Dias, D.A.; Urban, S.; Roessner, U. A historical overview of natural products in drug discovery. Metabolites 2012, 2, 303-336. [CrossRef] [PubMed]

9. Atanasov, A.G.; Waltenberger, B.; Pferschy-Wenzig, E.-M.; Linder, T.; Wawrosch, C.; Uhrin, P.; Temml, V.; Wang, L.; Schwaiger, S.; Heiss, E.H.; et al. Discovery and resupply of pharmacologically active plant-derived natural products: A review. Biotechnol. Adv. 2015, 33, 1582-1614. [CrossRef] [PubMed]

10. Khan, F.; Niaz, K.; Maqbool, F.; Hassan, F.I.; Abdollahi, M.; Venkata, K.C.N.; Nabavi, S.M.; Bishayee, A. Molecular targets underlying the anticancer effects of quercetin: An update. Nutrients 2016. [CrossRef] [PubMed]

11. Lozano-Perez, A.A.; Rivero, H.C.; Hernandez, M.C.P.; Pagan, A.; Montalban, M.G.; Villora, G.; Cenis, J.L. Silk fibroin nanoparticles: Efficient vehicles for the natural antioxidant quercetin. Int. J. Pharm. 2017, 518, 11-19. [CrossRef] [PubMed]

12. Kumar, S.S.; Surianarayanan, M.; Vijayaraghavan, R.; Mandal, A.B.; MacFarlane, D.R. Curcumin loaded poly(2-hydroxyethyl methacrylate) nanoparticles from gelled ionic liquid-In vitro cytotoxicity and anti-cancer activity in SKOV-3 cells. Eur. J. Pharm. Sci. 2014, 51, 34-44. [CrossRef] [PubMed]

13. Kumar, S.S.; Mahesh, A.; Mahadevan, S.; Mandal, A.B. Synthesis and characterization of curcumin loaded polymer/lipid based nanoparticles and evaluation of their antitumor effects on MCF-7 cells. Biochim. Biophys. Acta 2014, 1840, 1913-1922. [CrossRef] [PubMed]

14. Monroy, A.; Lithgow, G.J.; Alavez, S. Curcumin and neurodegenerative diseases. Biofactors 2013, 39, $122-132$. [CrossRef] [PubMed]

15. Olszanecki, R.; Jawien, J.; Gajda, M.; Mateuszuk, L.; Gebska, A.; Korabiowska, M.; Chlopicki, S.; Korbut, R. Effect of curcumin on atherosclerosis in apoE/LDLR-double knockout mice. J. Physiol. Pharmacol. 2005, 56, 627-635. [PubMed]

16. Wongcharoen, W.; Phrommintikul, A. The protective role of curcumin in cardiovascular diseases. Int. J. Cardiol. 2009, 133, 145-151. [CrossRef] [PubMed]

17. Park, W.; Ruhul Amin, A.R.M.; Chen, Z.G.; Shin, D.M. New perspectives of curcumin in cancer prevention. Cancer Prev. Res. (Phila) 2013, 6, 387-400. [CrossRef] [PubMed]

18. Aggarwal, B.B.; Harikumar, K.B. Potential therapeutic effects of curcumin, the anti-inflammatory agent, against neurodegenerative, cardiovascular, pulmonary, metabolic, autoimmune and neoplastic diseases. Int. J. Biochem. Cell Biol. 2009, 41, 40-59. [CrossRef] [PubMed]

19. Rivera-Espinoza, Y.; Muriel, P. Pharmacological actions of curcumin in liver diseases or damage. Liver Int. 2009, 29, 1457-1466. [CrossRef] [PubMed] 
20. Zhang, D.-W.; Fu, M.; Gao, S.-H.; Liu, J.-L. Curcumin and Diabetes: A Systematic Review. Evid. Based Complement. Altern. Med. 2013. [CrossRef] [PubMed]

21. Akbik, D.; Ghadiri, M.; Chrzanowski, W.; Rohanizadeh, R. Curcumin as a wound healing agent. Life Sci. 2014, 116, 1-7. [CrossRef] [PubMed]

22. Zheng, Z.; Sun, Y.; Liu, Z.; Zhang, M.; Li, C.; Cai, H. The effect of curcumin and its nanoformulation on adjuvant-induced arthritis in rats. Drug Des. Dev. Ther. 2015, 9, 4931-4942.

23. He, Y.; Yue, Y.; Zheng, X.; Zhang, K.; Chen, S.; Du, Z. Curcumin, inflammation, and chronic diseases: How are they linked? Molecules 2015, 20, 9183-9213. [CrossRef] [PubMed]

24. Ghosh, S.S.; Gehr, T.W.; Ghosh, S. Curcumin and chronic kidney disease (CKD): Major mode of action through stimulating endogenous intestinal alkaline phosphatase. Molecules 2014, 19, 20139-20156. [CrossRef] [PubMed]

25. Yao, Y.; Wang, W.; Li, M.; Ren, H.; Chen, C.; Wang, J.; Wang, W.E.; Yang, J.; Zeng, C. Curcumin Exerts its Anti-hypertensive Effect by Down-regulating the AT1 Receptor in Vascular Smooth Muscle Cells. Sci. Rep. 2016. [CrossRef] [PubMed]

26. Pescosolido, N.; Giannotti, R.; Plateroti, A.M.; Pascarella, A.; Nebbioso, M. Curcumin: Therapeutical potential in ophthalmology. Planta Med. 2014, 80, 249-254. [CrossRef] [PubMed]

27. Chen, Z.; Xue, J.; Shen, T.; Mu, S.; Fu, Q. Curcumin alleviates glucocorticoid-induced osteoporosis through the regulation of the Wnt signaling pathway. Int. J. Mol. Med. 2016, 37, 329-338. [CrossRef] [PubMed]

28. Thangapazham, R.L.; Sharma, A.; Maheshwari, R.K. Beneficial role of curcumin in skin diseases. Adv. Exp. Med. Biol. 2007, 595, 343-357. [PubMed]

29. Ghalandarlaki, N.; Alizadeh, A.M.; Ashkani-Esfahani, S. Nanotechnology-Applied curcumin for different diseases therapy. BioMed. Res. Int. 2014. [CrossRef] [PubMed]

30. Dende, C.; Meena, J.; Nagarajan, P.; Nagaraj, V.A.; Panda, A.K.; Padmanaban, G. Nanocurcumin is superior to native curcumin in preventing degenerative changes in Experimental Cerebral Malaria. Sci. Rep. 2017. [CrossRef] [PubMed]

31. Prasad, S.; Aggarwal, B.B. Turmeric, the golden spice: From traditional medicine. In Herbal Medicine: Biomolecular and Clinical Aspects, 2nd ed.; Benzie, I.F.F., Wachtel-Galor, S., Eds.; CRC Press/Taylor \& Francis: Boca Raton, FL, USA, 2011; ISBN 9781439807132.

32. Wright, L.E.; Frye, J.B.; Gorti, B.; Timmermann, B.N.; Funk, J.L. Bioactivity of Turmeric-Derived Curcuminoids and Related Metabolites in Breast Cancer. Curr. Pharm. Des. 2013, 19, 6218-6225. [CrossRef] [PubMed]

33. Lee, W.-H.; Loo, C.-Y.; Bebawy, M.; Luk, F.; Mason, R.S.; Rohanizadeh, R. Curcumin and its Derivatives: Their Application in Neuropharmacology and Neuroscience in the 21st Century. Curr. Neuropharmacol. 2013, 11, 338-378. [CrossRef] [PubMed]

34. Alok, A.; Singh, I.D.; Singh, S.; Kishore, M.; Jha, P.C. Curcumin-Pharmacological Actions and its Role in Oral Submucous Fibrosis: A Review. J. Clin. Diagn. Res. 2015, 9, ZE01-ZE03. [CrossRef] [PubMed]

35. Ucisik, M.H.; Kupcu, S.; Schuster, B.; Sleytr, U.B. Characterization of CurcuEmulsomes: Nanoformulation for enhanced solubility and delivery of curcumin. J. Nanobiotechnol. 2013. [CrossRef] [PubMed]

36. Iriti, M.; Vitalini, S.; Fico, G.; Faoro, F. Neuroprotective Herbs and Foods from Different Traditional Medicines and Diets. Molecules 2010, 15, 3517-3555. [CrossRef] [PubMed]

37. Maheshwari, R.; Singh, A.K.; Gaddipati, J.; Srimal, R.C. Multiple biological activities of curcumin: A short review. Life Sci. 2006, 78, 2081-2087. [CrossRef] [PubMed]

38. Anand, P.; Thomas, S.G.; Kunnumakkara, A.B.; Sundaram, C.; Harikumar, K.B.; Sung, B.; Tharakan, S.T.; Misra, K.; Priyadarsini, I.K.; Rajasekharan, K.N.; et al. Biological activities of curcumin and its analogues (Congeners) made by man and Mother Nature. Biochem. Pharmacol. 2008, 76, 1590-1611. [CrossRef] [PubMed]

39. Teow, S.-Y.; Liew, K.; Ali, S.A.; Khoo, A.S.; Peh, S.-C. Antibacterial action of curcumin against Staphylococcus aureus: A brief review. J. Trop. Med. 2016. [CrossRef] [PubMed]

40. Alwi, I.; Santoso, T.; Suyono, S.; Sutrisna, B.; Suyatna, F.D.; Kresno, S.B.; Ernie, S. The effect of curcumin on lipid level in patients with acute coronary syndrome. Acta Med. Indones. 2008, 40, 201-210. [PubMed]

41. Liu, Y. Curcumin: An Ingredient that Reduces Platelet Aggregation and Hyperlipidemia, and Enhances Antioxidant and Immune Functions. ACS Symp. Ser. 1997, 660, 199-205. 
42. Kim, D.C.; Ku, S.K.; Bae, J.S. Anticoagulant activities of curcumin and its derivative. BMP Rep. 2012, 45, 221-226. [CrossRef]

43. Wang, N.P.; Wang, Z.F.; Tootle, S.; Philip, T.; Zhao, Z.Q. Curcumin promotes cardiac repair and ameliorates cardiac dysfunction following myocardial infarction. Br. J. Pharmacol. 2012, 167, 1550-1562. [CrossRef] [PubMed]

44. Soetikno, V.; Suzuki, K.; Veeraveedu, P.T.; Arumugam, S.; Lakshmanan, A.P.; Sone, H.; Watanabe, K. Molecular understanding of curcumin in diabetic nephropathy. Drug Discov. Today 2013, 18, 756-763. [CrossRef] [PubMed]

45. Qureshi, M.; Al-Suhaimi, E.A.; Wahid, F.; Shehzad, O.; Shehzad, A. Therapeutic potential of curcumin for multiple sclerosis. Neurol. Sci. 2017. [CrossRef] [PubMed]

46. Lee, H.Y.; Kim, S.W.; Lee, G.H.; Choi, M.K.; Jung, H.W.; Kim, Y.J.; Kwon, H.J.; Chae, H.J. Turmeric extract and its active compound, curcumin, protect against chronic CCl4-induced liver damage by enhancing antioxidation. BMC Complement. Altern. Med. 2016. [CrossRef] [PubMed]

47. Shanmugam, M.K.; Rane, G.; Kanchi, M.M.; Arfuso, F.; Chinnathambi, A.; Zayed, M.E.; Alharbi, S.A.; Tan, B.K.; Kumar, A.P.; Sethi, G. The multifaceted role of curcumin in cancer prevention and treatment. Molecules 2015, 20, 2728-2769. [CrossRef] [PubMed]

48. Liu, X.-F.; Hao, J.-K.; Xie, T.; Mukhtar, N.J.; Zhang, W.; Malik, T.H.; Lu, C.-W.; Zhou, D.-D. Curcumin, a Potential Therapeutic Candidate for Anterior Segment Eye Diseases: A Review. Front. Pharmacol. 2017. [CrossRef] [PubMed]

49. Beevers, C.S.; Huang, S. Pharmacological and clinical properties of curcumin. Botanics 2011. [CrossRef]

50. Zhao, J.-F.; Ching, L.-C.; Huang, Y.-C.; Chen, C.-Y.; Chiang, A.-N.; Kou, Y.R.; Shyue, S.-K.; Lee, T.-S. Molecular mechanism of curcumin on the suppression of cholesterol accumulation in macrophage foam cells and atherosclerosis. Mol. Nutr. Food Res. 2012, 56, 691-701. [CrossRef] [PubMed]

51. Naidu, K.A.; Thippeswamy, N.B. Inhibition of human low density lipoprotein oxidation by active principles from spices. Mol. Cell. Biochem. 2002, 229, 19-23. [CrossRef] [PubMed]

52. Kempaiah, R.K.; Srinivasan, K. Integrity of erythrocytes of hypercholesterolemic rats during spices treatment. Mol. Cell Biochem. 2002, 236, 155-161. [CrossRef] [PubMed]

53. Tuorkey, M.J. Curcumin a potent cancer preventive agent: Mechanisms of cancer cell killing. Interv. Med. Appl. Sci. 2014, 6, 139-146. [CrossRef] [PubMed]

54. Sun, X.; Liu, Y.; Li, C.; Wang, X.; Zhu, R.; Liu, C.; Liu, H.; Wang, L.; Ma, R.; Fu, M.; et al. Recent Advances of Curcumin in the Prevention and Treatment of Renal Fibrosis. BioMed. Res. Int. 2017. [CrossRef] [PubMed]

55. Ghorbani, Z.; Hekmatdoost, A.; Mirmiran, P. Anti-hyperglycemic and insulin sensitizer effects of turmeric and its principle constituent curcumin. Int. J Endocrinol. Metab. 2014. [CrossRef] [PubMed]

56. Tang, M.; Taghibiglou, C. The mechanisms of action of curcumin in Alzheimer's disease. J. Alzheimers Dis. 2017, 58, 1003-1016. [CrossRef] [PubMed]

57. Li, G.; Bu, J.; Zhu, Y.; Xiao, X.; Liang, Z.; Zhang, R. Curcumin improves bone microarchitecture in glucocorticoid-induced secondary osteoporosis mice through the activation of microRNA-365 via regulating MMP-9. Int. J. Clin. Exp. Pathol. 2015, 8, 15684-15695. [PubMed]

58. Kumar, K.; Rai, A.K. Curcumin: A yellow magical spice of kitchen for treatment of rheumatoid arthritis. Int. Res. J. Pharm. 2011, 2, 29-31.

59. Shin, S.-K.; Ha, T.-Y.; McGregor, R.A.; Choi, M.-S. Long-term curcumin administration protects against atherosclerosis via hepatic regulation of lipoprotein cholesterol metabolism. Mol. Nutr. Food Res. 2011, 55, 1829-1840. [CrossRef] [PubMed]

60. Anand, P.; Sundaram, C.; Jhurani, S.; Kunnumakkara, A.B.; Aggarwal, B.B. Curcumin and cancer: An "old-age" disease with an "age-old" solution. Cancer Lett. 2008, 267, 133-164. [CrossRef] [PubMed]

61. Sikora, E.; Scapagnini, G.; Barbagallo, M. Curcumin, inflammation, ageing and age-related diseases. Immun. Ageing 2010. [CrossRef] [PubMed]

62. Sundar, D.S.; Antoniraj, M.G.; Kumar, C.S.; Mohapatra, S.S.; Houreld, N.N.; Ruckmani, K. Recent Trends of Biocompatible and Biodegradable Nanoparticles in Drug Delivery: A Review. Curr. Med. Chem. 2016, 23, 3730-3751. [CrossRef] [PubMed]

63. Baetke, S.C.; Lammers, T.; Kiessling, F. Applications of nanoparticles for diagnosis and therapy of cancer. Br. J. Radiol. 2015. [CrossRef] [PubMed] 
64. Flora, G.; Gupta, D.; Tiwari, A. Nanocurcumin: A promising therapeutic advancement over native curcumin. Crit. Rev. Ther. Drug Carrier Syst. 2013, 30, 331-368. [CrossRef] [PubMed]

65. Ahmad, M.Z.; Akhter, S.; Mohsin, N.; Abdel-Wahab, B.A.; Ahmad, J.; Warsi, M.H.; Rahman, M.; Mallick, N.; Ahmad, F.J. Transformation of curcumin from food additive to multifunctional medicine: Nanotechnology bridging the gap. Curr. Drug Discov. Technol. 2014, 11, 197-213. [CrossRef] [PubMed]

66. Ameruoso, A.; Palomba, R.; Palange, A.L.; Cervadoro, A.; Lee, A.; Mascolo, D.D.; Decuzzi, P. Ameliorating Amyloid- $\beta$ Fibrils Triggered Inflammation via Curcumin-Loaded Polymeric Nanoconstructs. Front. Immunol. 2017. [CrossRef] [PubMed]

67. Cheng, K.K.; Chan, P.S.; Fan, S.; Kwan, S.M.; Yeung, K.L.; Wang, Y.X.; Chow, A.H.; Wu, E.X.; Baum, L. Curcumin-conjugated magnetic nanoparticles for detecting amyloid plaques in Alzheimer's disease mice using magnetic resonance imaging (MRI). Biomaterials 2015, 44, 155-172. [CrossRef] [PubMed]

68. Dhivya, R.; Ranjani, J.; Rajendhran, J.; Mayandi, J.; Annaraj, J. Enhancing the anti-gastric cancer activity of curcumin with biocompatible and pH sensitive PMMA-AA/ZnO nanoparticles. Mater. Sci. Eng. C 2018, 82, 182-189. [CrossRef] [PubMed]

69. Yallapu, M.M.; Khan, S.; Maher, D.M.; Ebeling, M.C.; Sundram, V.; Chauhan, N.; Ganju, A.; Balakrishna, S.; Gupta, B.K.; Zafar, N.; et al. Anti-cancer activity of curcumin loaded nanoparticles in prostate cancer. Biomaterials 2014, 35, 8635-8648. [CrossRef] [PubMed]

70. Meena, R.; Kumar, S.; Kumar, R.; Gaharwar, U.S.; Rajamani, P. PLGA-CTAB curcumin nanoparticles: Fabrication, characterization and molecular basis of anticancer activity in triple negative breast cancer cell lines (MDA-MB-231 cells). Biomed. Pharmacother. 2017, 94, 944-954. [CrossRef] [PubMed]

71. Fan, Y.; Yi, J.; Zhang, Y.; Yokoyama, W. Fabrication of curcumin-loaded bovine serum albumin (BSA)-dextran nanoparticles and the cellular antioxidant activity. Food Chem. 2018, 239, 1210-1218. [CrossRef] [PubMed]

72. Wang, J.; Wang, H.; Zhu, R.; Liu, Q.; Fei, J.; Wang, S. Anti-inflammatory activity of curcumin-loaded solid lipid nanoparticles in IL-1b transgenic mice subjected to the lipopolysaccharide-induced sepsis. Biomaterials 2015, 53, 475-483. [CrossRef] [PubMed]

73. Li, J.; Zhou, Y.; Zhang, W.; Bao, C.; Xie, Z. Relief of oxidative stress and cardiomyocyte apoptosis by using curcumin nanoparticles. Colloids Surf. B 2017, 153, 174-182. [CrossRef] [PubMed]

74. Dewangan, A.K.; Perumal, Y.; Pavurala, N.; Chopra, K.; Mazumder, S. Preparation, characterization and anti-inflammatory effects of curcumin loaded carboxymethyl cellulose acetate butyrate nanoparticles on adjuvant induced arthritis in rats. J. Drug Deliv. Sci. Technol. 2017, 41, 269-279. [CrossRef]

75. Ahn, J.; Jeong, J.; Lee, H.; Sung, M.-J.; Jung, C.H.; Lee, H.; Hur, J.; Park, J.H.; Jang, Y.J.; Ha, T.Y. Poly(lactic-co-glycolic acid) Nanoparticles Potentiate the Protective Effect of Curcumin against Bone Loss in Ovariectomized Rats. J. Biomed. Nanotechnol. 2017, 13, 688-698. [CrossRef]

76. Li, M.; Xin, M.; Guo, C.; Lin, G.; Wu, X. New nanomicelle curcumin formulation for ocular delivery: Improved stability, solubility, and ocular anti-inflammatory treatment. Drug Dev. Ind. Pharm. 2017, 43, 1846-1857. [CrossRef] [PubMed]

77. Lin, Y.L.; Liu, Y.K.; Tsai, N.M.; Hsieh, J.H.; Chen, C.H.; Lin, C.M.; Liao, K.W. A Lipo-PEG-PEI complex for encapsulating curcumin that enhances its antitumor effects on curcumin-sensitive and curcumin-resistance cells. Nanomedicine 2012, 8, 318-327. [CrossRef] [PubMed]

78. Montalban, M.G.; Coburn, J.M.; Lozano-Perez, A.A.; Cenis, J.L.; Villora, G.; Kaplan, D.L. Production of curcumin-loaded silk fibroin nanoparticles for cancer therapy. Nanomaterials 2018. [CrossRef] [PubMed]

79. Sunagawa, Y.; Wada, H.; Suzuki, H.; Sasaki, H.; Imaizumi, A.; Fukuda, H.; Hashimoto, T.; Katanasaka, Y.; Shimatsu, A.; Kimura, T.; et al. A Novel Drug Delivery System of Oral Curcumin Markedly Improves Efficacy of Treatment for Heart Failure after Myocardial Infarction in Rats. Biol. Pharm. Bull. 2012, 35, 139-144. [CrossRef] [PubMed]

80. Young, N.A.; Wu, L.-C.; Gardner, M.; Hampton, J.; Bruss, M.; Jarjour, W. AB0185 Nano-Emulsified Curcumin (NEC), a Patented Anti-Inflammatory Nutraceutical Compound Developed at Ohio State, Reduces Renal Pathology in an Animal Model of Lupus Nephritis. Ann. Rheum. Dis. 2015, 74, 952-953. [CrossRef]

81. Chen, X.; Sun, J.; Li, H.; Wang, H.; Lin, Y.; Hu, Y.; Zheng, D. Curcumin-Loaded Nanoparticles Protect Against Rhabdomyolysis-Induced Acute Kidney Injury. Cell. Physiol. Biochem. 2017, 43, 2143-2154. [CrossRef] [PubMed] 
82. Cheng, K.K.; Yeung, C.F.; Ho, S.W.; Chow, S.F.; Chow, A.H.L.; Baum, L. Highly Stabilized Curcumin Nanoparticles Tested in an in Vitro Blood-Brain Barrier Model and in Alzheimer's Disease Tg2576 Mice. AAPS J. 2013, 15, 324-336. [CrossRef] [PubMed]

83. Grama, C.N.; Suryanarayana, P.; Patil, M.A.; Raghu, G.; Balakrishna, N.; Ravi Kumar, M.N.V.; Reddy, G.B. Efficacy of Biodegradable Curcumin Nanoparticles in Delaying Cataract in Diabetic Rat Model. PLoS ONE 2013. [CrossRef] [PubMed]

84. Heo, D.N.; Ko, W.-K.; Moon, H.-J.; Kim, H.-J.; Lee, S.J.; Lee, J.B.; Bae, M.S.; Yi, J.K.; Hwang, Y.S.; Bang, J.B.; et al. Inhibition of Osteoclast Differentiation by Gold Nanoparticles Functionalized with Cyclodextrin Curcumin Complexes. ACS Nano 2014, 8, 12049-12062. [CrossRef] [PubMed]

85. Effects of Short-Term Curcumin and Multi-Polyphenol Supplementation on the Anti-Inflammatory Properties of HDL (PSI). Available online: https:/ / clinicaltrials.gov/ct2/show / NCT02998918 (accessed on 25 January 2018).

86. Curcumin in Preventing Colorectal Cancer in Patients Undergoing Colorectal Endoscopy or Colorectal Surgery. Available online: https://clinicaltrials.gov/ct2/show/record/NCT00973869 (accessed on 25 January 2018).

87. The Effect of Diet on Chronic Inflammation and Related Disorders Following Spinal Cord Injury. Available online: https: / / clinicaltrials.gov/ct2/show/record/NCT02099890 (accessed on 25 January 2018).

88. Micro-Particle Curcumin for the Treatment of Chronic Kidney Disease (MPAC-CKD). Available online: https: / clinicaltrials.gov/ct2/show / NCT02369549 (accessed on 25 January 2018).

89. Effects of Curcumin Supplementation on Lipid Profile and Inflammatory Markers of Patients with Type 2 Diabetes. Available online: https:/ / clinicaltrials.gov/ct2/show/NCT02529969 (accessed on 25 January 2018).

90. Safety and Efficacy of Anti-Oxidants and Anti-Inflammatory Agents in Glaucoma and Diabetic Retinopathy. Available online: https:/ / clinicaltrials.gov/ct2/show /NCT02984813 (accessed on 25 January 2018).

91. A Pilot Study of Curcumin and Ginkgo for Treating Alzheimer's Disease. Available online: https: / / clinicaltrials.gov/ct2/show / NCT00164749 (accessed on 25 January 2018).

92. Curcumin in Rheumatoid Arthritis. Available online: https:/ / clinicaltrials.gov/ct2/show / NCT00752154 (accessed on 25 January 2018). 